\title{
Bordetella hinzii sp. nov., Isolated from Poultry and Humans
}

\author{
P. VANDAMME, ${ }^{1 *}$ J. HOMMEZ, ${ }^{2}$ M. VANCANNEYT, ${ }^{1}$ M. MONSIEURS,${ }^{1}$ B. HOSTE,${ }^{1}$ B. COOKSON,${ }^{3}$ \\ C. H. WIRSING VON KÖNIG, ${ }^{4}$ K. KERSTERS, ${ }^{1}$ AND P. J. BLACKALL ${ }^{5}$ \\ Laboratorium voor Microbiologie, University of Ghent, B-9000 Ghent, ${ }^{1}$ and Provinciaal Verbond voor Dierenziektenbestrijding, \\ Torhout ${ }^{2}$ Belgium; Department of Laboratory Medicine SB-10, University of Washington Medical Center, Seattle, \\ Washington 981953; Institute for Hygiene and Laboratory Medicine, Städtische Krankenanstalten \\ Krefeld, Germany ; and Queensland Department of Primary Industries, Animal \\ Research Institute, Yeerongpilly, Queensland 4105, Australia ${ }^{5}$
}

\begin{abstract}
A polyphasic taxonomic study that included DNA-rRNA hybridizations, DNA-DNA hybridizations, DNA base ratio determinations, whole-cell protein and fatty acid analyses, and an examination of classical phenotypic characteristics was performed in order to classify human and veterinary isolates that resemble Bordetella avium. Twelve poultry isolates and two human isolates were assigned to a new species, for which we propose the name Bordetella hinzii. The position of this organism in the family Alcaligenaceae and various genotypic, phenotypic, and chemotaxonomic characteristics are described.
\end{abstract}

Members of the genus Bordetella are well-known pathogens of humans and animals (39). The significance of Bordetella pertussis, Bordetella parapertussis, and Bordetella bronchiseptica as respiratory tract invaders, with whooping cough as the most important infection, is well-known (39). A less familiar member of the genus, Bordetella avium, causes respiratory infections in poultry (22). These infections result in high levels of morbidity and are responsible for significant losses in both the turkey and chicken industries $(3,6,17,28,32,33)$. Strains of another taxon, which has been referred to as $B$. avium-like, Alcaligenes faecalis type II, TC (turkey coryza) bacterium type II, or Alcaligenes sp. strain $\mathrm{C}_{2} \mathrm{~T}_{2}$, have also been isolated from respiratory tracts of chickens and turkeys in various parts of the world $(1,3,19,20,31)$. Although these strains are often isolated from diseased birds, the information available does not provide strong evidence that they are pathogenic $(3,19)$.

In this study, we performed a polyphasic taxonomic study in order to clarify the taxonomic position of the $B$. avium-like taxon. Below, we show that 12 poultry isolates and 2 human isolates of the B. avium-like taxon constitute a novel Bordetella species, for which we propose the name Bordetella hinzii sp. nov.

\section{MATERIALS AND METHODS}

Bacterial strains and growth conditions. All of the strains which we studied and their sources are listed in Table 1 . Bacteriological purity was checked by plating and examining living cells, using phase-contrast microscopy and Gramstained cells.

B. pertussis strains were grown as described by Stainer and Scholte (34). All other strains were grown on Trypticase soy agar (catalog no. 11768; BBL, Becton Dickinson Microbiology Systems, Cockeysville, Md.) and were incubated aerobically at 36 to $37^{\circ} \mathrm{C}$ unless indicated otherwise.

PAGE of whole-cell proteins. After incubation for $48 \mathrm{~h}$, whole-cell protein extracts were prepared, and sodium dodecyl sulfate (SDS)-polyacrylamide gel electrophoresis (PAGE) was performed as described previously (30). A densitometric analysis, normalization and interpolation of the protein profiles, and a numerical analysis were performed by using the GelCompar software package (Applied Maths, Kortrijk, Belgium).

Fatty acid methyl ester analysis. After incubation for $48 \mathrm{~h}$, a loopful of well-grown cells was harvested, and fatty acid methyl esters were prepared, separated, and identified by using the Microbial Identification System (Microbial ID, Inc., Newark, Del.) as described previously (37).

* Corresponding author. Mailing address: Laboratorium voor Microbiologie, Universiteit Gent, K. L. Ledeganckstraat 35, B-9000 Ghent, Belgium. Phone: (32)9.264.51.14. Fax: (32)9.264.53.46.
Preparation of high-molecular-weight DNA. High-molecular-weight native DNA was prepared as described previously (37).

DNA base compositions. All of the mean guanine-plus-cytosine $(G+C)$ values were determined by the thermal denaturation method, and were calculated as described by De Ley (11).

DNA-DNA hybridization experiments. The degrees of DNA-DNA binding, expressed as percentages, were determined spectrophotometrically by the initial renaturation rate method of De Ley et al. (12). Each value given below is the average of the values from at least two hybridization experiments. DNA binding values of $30 \%$ and less indicate that the level of DNA homology is not significant. The total DNA concentration was $48 \mu \mathrm{g} / \mathrm{ml}$, and the optimal renaturation temperature in $2 \times \mathrm{SSC}(1 \times \mathrm{SSC}$ is $0.15 \mathrm{M} \mathrm{NaCl}$ plus $0.015 \mathrm{M}$ sodium citrate, $\mathrm{pH}$ 7) was $80.5^{\circ} \mathrm{C}$.

DNA-rRNA hybridization experiments. In vivo radioactively labelled $23 \mathrm{~S}$ rRNA from $B$. hinzii LMG $13501^{\mathrm{T}}(\mathrm{T}=$ type strain) was prepared as described previously (36).

Purification of rRNA fractions, fixation of single-stranded DNA on membrane filters, chemical determinations of the amounts of DNA on the filters, saturation hybridization, RNase treatment, and thermostability measurements of the hybrids were performed as described by Van Landschoot and De Ley (38). Each DNA-rRNA hybrid was characterized by its melting temperature of elution $\left[T_{m(e)}\right]$, the temperature at which $50 \%$ of the hybrid was denatured. The higher the $T_{m(e)}$ of a heterologous hybrid, the closer the two strains are related. The $T_{m(e)}$ values obtained from reciprocal hybridization experiments in which all strains belonging to each rRNA branch were compared were used to calculate the average linkage level between each pair of rRNA branches.

Phenotypic tests. Strains were grown on brain heart infusion base (catalog no. 11037 ; BBL) supplemented with 5\% sheep blood for maintenance of cultures and preparation of inocula for biochemical tests. The other media used are described below. Blood agar plates were incubated in air containing $5 \% \mathrm{CO}_{2}$; other media were incubated aerobically. The incubation temperature was $37^{\circ} \mathrm{C}$ unless indicated otherwise.

The gram stain reaction was assessed by using cells obtained from cultures incubated on blood agar for $16 \mathrm{~h}$. The occurrence and distribution of flagella were determined by electron microscopy, using a phosphotungstic acid negative stain on cultures grown overnight in nutrient broth incubated at room temperature. Oxidase activity was tested by using 18-h-old cultures and a Marion oxidase dropper (Marion Scientific). Alkalinization of amides and organic salts was determined by using a modified Greenwood low-peptone medium (29), as previously described (4). Briefly, the basal medium contained $0.1 \mathrm{~g}$ of $\left(\mathrm{NH}_{4}\right)_{2} \mathrm{HPO}_{4}, 0.02 \mathrm{~g}$ of $\mathrm{KCl}, 0.2 \mathrm{~g}$ of $\mathrm{MgSO}_{4} \cdot 7 \mathrm{H}_{2} \mathrm{O}, 0.05 \mathrm{~g}$ of yeast extract, 0.05 $\mathrm{g}$ of Casitone, $0.02 \mathrm{~g}$ of glucose, $1.5 \mathrm{~g}$ of agar, $2.5 \mathrm{ml}$ of a $0.4 \%$ aqueous solution of bromthymol blue, and $100 \mathrm{ml}$ of distilled water. The basal medium was adjusted to $\mathrm{pH} 6.5$ before sterilization and autoclaving. The amides and organic salts were sterilized by filtration and were added to the basal medium to final concentrations of $1 \%(\mathrm{wt} / \mathrm{vol})$. The completed test media were dispensed as $3-\mathrm{ml}$ slants in cotton wool-plugged glass tubes (110 by $13 \mathrm{~mm})$. Growth from a $16-\mathrm{h}$ culture on blood agar was heavily streaked onto the slant of medium in each tube. The substrates used were acetamide, disodium adipate, glycine, malonamide, sodium malonate, sodium valerate, and propionamide. A dark blue color, which indicated an alkaline $\mathrm{pH}$, was recorded as positive. Standard methods were used for all other biochemical tests (10). The urease test medium used was a liquid version of Christensen's medium (catalog no. CM71; Oxoid). Unless otherwise indicated, the inoculated test media were observed daily, and the final reading was obtained after 5 days.

The API 20NE MicroTest system was used according to the recommendations 
TABLE 1. Strains studied

\begin{tabular}{|c|c|c|c|c|}
\hline Strain $^{a}$ & Taxon & Original designation $(\mathrm{s})^{a}$ & Depositor(s) ${ }^{a, b}$ & Source (if known) \\
\hline LMG $1229^{\mathrm{T}}$ & Alcaligenes faecalis & NCIB $8156^{\mathrm{T}}$, ATCC $8750^{\mathrm{T}}$ & NCIB, ATCC & \\
\hline LMG 1230 & Alcaligenes faecalis & CCEB 554 & CCEB & Feces (Czechoslovakia) \\
\hline LMG 1861 & Alcaligenes piechaudii & NCMB 1051 & Torry Research Station & Soil \\
\hline LMG $1873^{\mathrm{T}}$ & Alcaligenes piechaudii & CIP $60.75^{\mathrm{T}}$ & CIP & Pharynx \\
\hline LMG $1231^{\mathrm{T}}$ & $\begin{array}{l}\text { Alcaligenes xylosoxidans } \\
\text { subsp. denitrificans }\end{array}$ & ATCC $15173^{\mathrm{T}}$ & ATCC & Soil \\
\hline LMG $1863^{\mathrm{T}}$ & $\begin{array}{l}\text { Alcaligenes xylosoxidans } \\
\text { subsp. sylosoxidans }\end{array}$ & ATCC $27061^{\mathrm{T}}$ & E. Yabuuchi & Human ear discharge (Japan) \\
\hline LMG 10973 & Bordetella avium & Hommez 15 & & $\begin{array}{l}\text { Trachea of broiler chicken with slight respiratory signs } \\
\text { and tracheitis (1989, Torhout, Belgium) }\end{array}$ \\
\hline LMG 10974 & Bordetella avium & Hommez 16 & & Chicken with coryza (Torhout, Belgium) \\
\hline LMG 10975 & Bordetella avium & Hommez 17 & & $\begin{array}{l}\text { Trachea of chicken with coryza, dyspnea, lung } \\
\text { congestion, and slight tracheitis (1988, Torhout, } \\
\text { Belgium) }\end{array}$ \\
\hline LMG 10976 & Bordetella avium & Hommez 18 & & $\begin{array}{l}\text { Spleen of chicken with Marek's disease } \\
\text { (1989, Torhout, Belgium) }\end{array}$ \\
\hline LMG 10977 & Bordetella avium & Hommez 19 & & $\begin{array}{l}\text { Trachea of broiler chicken with coryza-like symptoms } \\
\text { and slight tracheitis (1988, Torhout, Belgium) }\end{array}$ \\
\hline LMG 10978 & Bordetella avium & Hommez 20 & & $\begin{array}{l}\text { Trachea of broiler chicken with slight tracheitis and } \\
\text { polyserositis (1988, Torhout, Belgium) }\end{array}$ \\
\hline LMG 1851 & Bordetella avium & Hinz 363-78 & K.-H. Hinz & Turkey with turkey coryza, respiratory tract (Germany) \\
\hline LMG $1852^{\mathrm{T}}$ & Bordetella avium & Hinz $591-77^{\mathrm{T}}$, ATCC $35086^{\mathrm{T}}$ & K.-H. Hinz, ATCC & Turkey, air sac exudate (Germany) \\
\hline LMG 1854 & Bordetella avium & Rimler P-4085 & K.-H. Hinz & Turkey (United States) \\
\hline LMG 1858 & Bordetella avium & Simmons strain NC & K.-H. Hinz & Turkey (United States) \\
\hline LMG 3524 & Bordetella avium & Hinz 946-77 & K.-H. Hinz & Turkey with turkey coryza, lung (Germany) \\
\hline LMG 3549 & Bordetella avium & Hinz 2-81 & K.-H. Hinz & Turkey (United Kingdom) \\
\hline LMG 3557 & Bordetella avium & Hinz 298-81 & K.-H. Hinz & Duck, trachea (Germany) \\
\hline LMG $1232^{\mathrm{T}}$ & Bordetella bronchiseptica & NCTC $452^{\mathrm{T}}$, ATCC $19395^{\mathrm{T}}$ & NCTC, ATCC & Dog, lung \\
\hline LMG 3521 & Bordetella bronchiseptica & Hinz 40-81 & K.-H. Hinz & Turkey, trachea (Germany) \\
\hline LMG 10979 & Bordetella hinzii & Hommez 6, TC102 & & Chicken with slight tracheitis (Torhout, Belgium) \\
\hline LMG 10980 & Bordetella hinzii & Hommez 7, TC103 & & Chicken with slight tracheitis (Torhout, Belgium) \\
\hline LMG 13494 & Bordetella hinzii & TC18 & & Chicken, sinus (Australia) \\
\hline LMG 13495 & Bordetella hinzii & $\mathrm{TC} 27$ & & Chicken, trachea (Australia) \\
\hline LMG 13496 & Bordetella hinzii & TC32 & & Chicken, trachea (Australia) \\
\hline LMG 13497 & Bordetella hinzii & TC33 & & Chicken, sinus (Australia) \\
\hline LMG 13498 & Bordetella hinzii & TC36 & & Chicken, trachea (Australia) \\
\hline LMG 13499 & Bordetella hinzii & TC38 & & Chicken, trachea (Australia) \\
\hline LMG 13500 & Bordetella hinzii & TC52 & & Chicken, trachea (Australia) \\
\hline LMG $13501^{\mathrm{T}}$ & Bordetella hinzii & $\mathrm{TC}^{\mathrm{T}} 8^{\mathrm{T}}$ & & Chicken, trachea (Australia) \\
\hline LMG 13504 & Bordetella hinzii & TC81 & & Chicken, trachea (Australia) \\
\hline LMG 13505 & Bordetella hinzii & TC82 & & Chicken, trachea (Australia) \\
\hline LMG 14052 & Bordetella hinzii & TC104 & & AIDS patient (United States) \\
\hline LMG 1872 & Bordetella hinzii & CIP 57.58, TC101 & CIP & Sputum (France) \\
\hline LMG 1816 & $\begin{array}{l}\text { Bordetella parapertussis } \\
\text { Bordetella pertussis }\end{array}$ & $\begin{array}{l}\text { NCTC } 7385 \\
\text { NIH L4 }\end{array}$ & NCTC & \\
\hline LMG 13506 & Bordetella sp. & 1779 & & Chronic otitis media, human (Germany) \\
\hline
\end{tabular}

${ }^{a}$ ATCC, American Type Culture Collection, Rockville, Md.; CCEB, Culture Collection of Entomogenous Bacteria, Department of Insect Pathology, Institute of Entomology, Prague, Czechoslovakia; CIP, Collection bactérienne de l'Institut Pasteur, Paris, France; LMG, Laboratorium Microbiologie Gent Culture Collection, Universiteit Gent, Ghent, Belgium; NCIB, National Collection of Industrial Bacteria, NCIMB, Ltd., Aberdeen, Scotland; NCMB, National Collection of Marine Bacteria, NCIMB, Ltd., Aberdeen, Scotland; NCTC, National Collection of Type Cultures, Central Public Health Laboratory, London, United Kingdom; NIH, National Institutes of Health, Bethesda, Md.

${ }^{b}$ Our isolate if not specified.

of the manufacturer (bioMérieux, La Balme-les-Grottes, Montalieu-Vercieu, France).

\section{RESULTS}

PAGE of whole-cell proteins. Duplicate protein extracts were prepared to check the reproducibility of the growth conditions and the preparation of the extracts. The levels of correlation $(r)$ between duplicate protein patterns were $\geq 0.94$.

The protein profiles and the corresponding dendrogram obtained after numerical analysis are shown in Fig. 1. Seven stable clusters and four strains that occupied separate positions were differentiated. Clusters I, II, and V comprised Alcaligenes piechaudii, $A$. faecalis, and $B$. bronchiseptica reference strains that grouped at $r$ values of $0.93,0.92$, and 0.84 , respectively. Clusters III and IV contained $B$. hinzii strains that grouped at $r$ values of more than 0.84 . Clusters VI and VII contained $B$. avium strains that grouped at $r$ values of more than 0.83 and 0.89 , respectively. The Alcaligenes xylosoxidans subsp. xylosoxidans and $A$. xylosoxidans subsp. denitrificans reference strains and strains LMG 1872 (B. hinzii) and LMG 13506 occupied separate positions on the dendrogram.

The major difference between the protein profiles of the $B$. hinzii strains belonging to clusters III and IV was the position of a prominent protein band that had a molecular weight of approximately 33,000 (Fig. 1). In addition, the position of a second protein band (molecular weight, approximately 23,000 


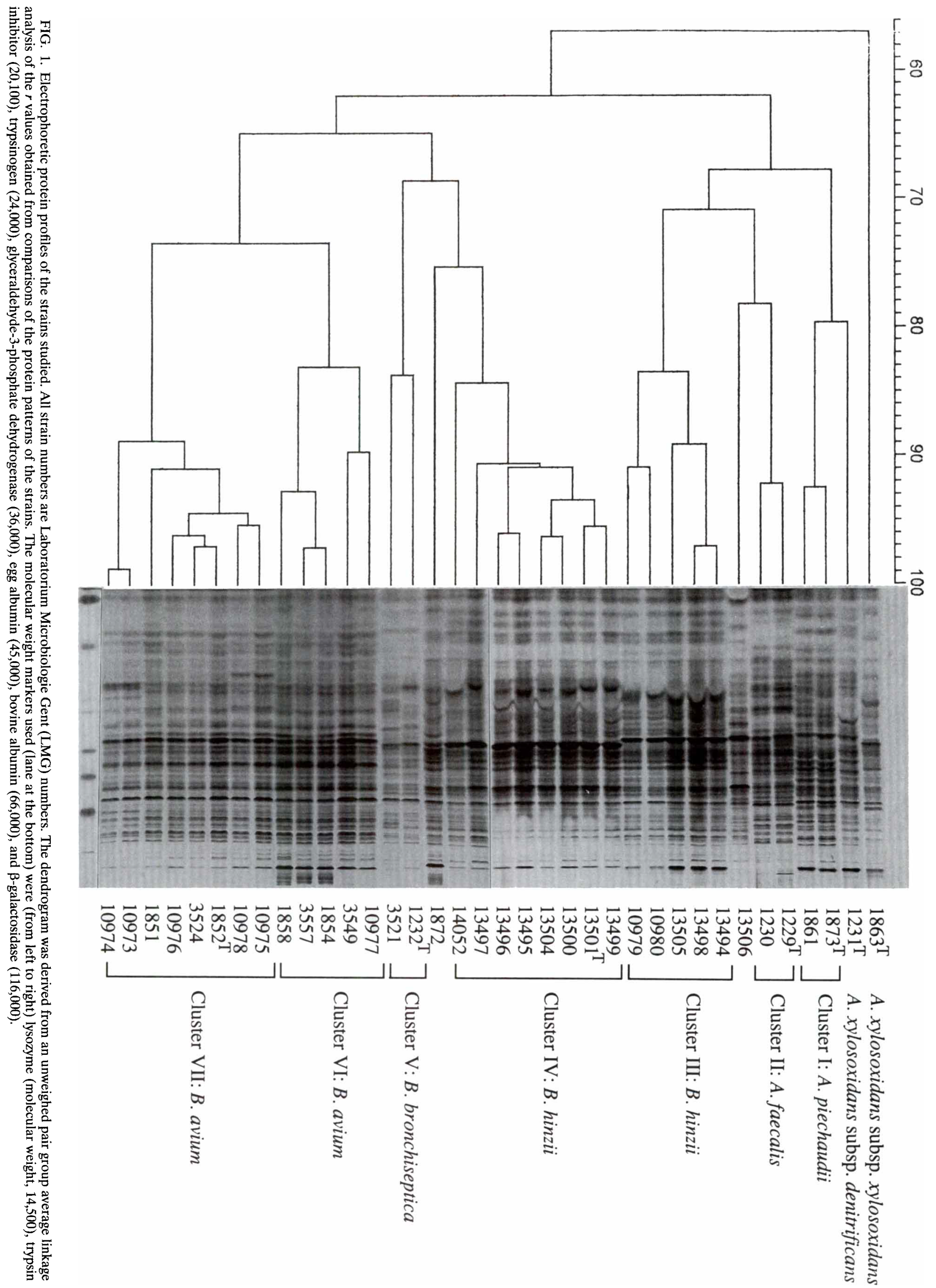


[Fig. 1]) differed in cluster III and IV strains. The protein pattern of $B$. hinzii LMG 1872 was distorted, although it was virtually identical to the protein patterns of the cluster III strains. A second protein extract was prepared, but the same distortion was found (data not shown). In general, the differences between the $B$. avium strains belonging to clusters VI and VII were restricted to differences in one high-molecularweight protein band which was prominent in cluster VI strains but less prominent in cluster VII strains (molecular weight, more than 116,000 [Fig. 1]).

Cellular fatty acid analysis. The major fatty acid components of all of the strains examined were 16:0, 17:0 cyclo, and summed feature 3 . Summed feature 3 comprised two fatty acids which could not be distinguished by the Microbial Identification System, 16:1 iso I and 14:0 3OH. Branched-chain fatty acids have not been reported in Bordetella or Alcaligenes strains, or they are present only in trace amounts in some strains (20). Therefore, the peak designated summed feature 3 probably corresponds to $14: 03 \mathrm{OH}$. The major fatty acids accounted for $75 \%$ or more of the total fatty acid contents of all of the strains studied and were not useful for differentiating the various taxa.

The average fatty acid compositions of all species were calculated, and these compositions are shown in Table 2.

DNA base compositions. All of the DNA base ratios determined are shown in Table 3. The $B$. hinzii strains had DNA base ratios of 65 to $67 \mathrm{~mol} \%$, values which are similar to the $B$. pertussis, $B$. parapertussis, and $B$. bronchiseptica values. $B$. avium remained the most aberrant member of the genus Bordetella, with a $\mathrm{G}+\mathrm{C}$ content of 61 to $62 \mathrm{~mol} \%$.

DNA-DNA hybridization experiments. The results of the DNA-DNA hybridization study indicated that the $B$. hinzii strains belonging to electrophoretic clusters III and IV and strain LMG 1872 constitute a homogeneous genospecies (DNA binding values, $\geq 67 \%$ ) (Table 3 ). No significant DNA binding values were obtained when these strains were hybridized with strain LMG 13506 or reference strains of other Bordetella or Alcaligenes species.

The $B$. avium strains belonging to clusters VI and VII were highly related (DNA binding value, 95\%).

$B$. pertussis, $B$. parapertussis, and $B$. bronchiseptica constituted a single, homogeneous genospecies (DNA binding values, $>76 \%$ ). These data confirmed the findings of Kloos et al. (25) and indicated that these three species can be considered subtypes of a single species (25).

Reference strains of all taxa were cross-hybridized, and no significant DNA binding values were obtained (except when $B$. pertussis, $B$. parapertussis, and $B$. bronchiseptica were used [see above]).

DNA-rRNA hybridization experiments. The DNA-rRNA hybridization results are shown in Table 4 . The average linkage levels in the dendrogram in Fig. 2 are based on the $T_{m(e)}$ values which we obtained and on previously published data (13).

Phenotypic tests. All $B$. hinzii strains, together with the type strains of $B$. avium, $B$. bronchiseptica, and $A$. faecalis, were examined for phenotypic characteristics. All of the strains were gram-negative rod-shaped organisms that were motile by means of peritrichous flagella. All strains produced catalase and oxidase and gave an alkaline reaction in the oxidativefermentative test.

When the API 20NE MicroTest system was used, the following characteristics were always negative: reduction of nitrate (except $B$. bronchiseptica ATCC $19395^{\mathrm{T}}$ ), production of indole, production of acid from glucose, urease activity (except B. bronchiseptica ATCC $19395^{\mathrm{T}}$ ), arginine dihydrolase and $\beta$-galactosidase activities, liquefaction of gelatin, hydrolysis of

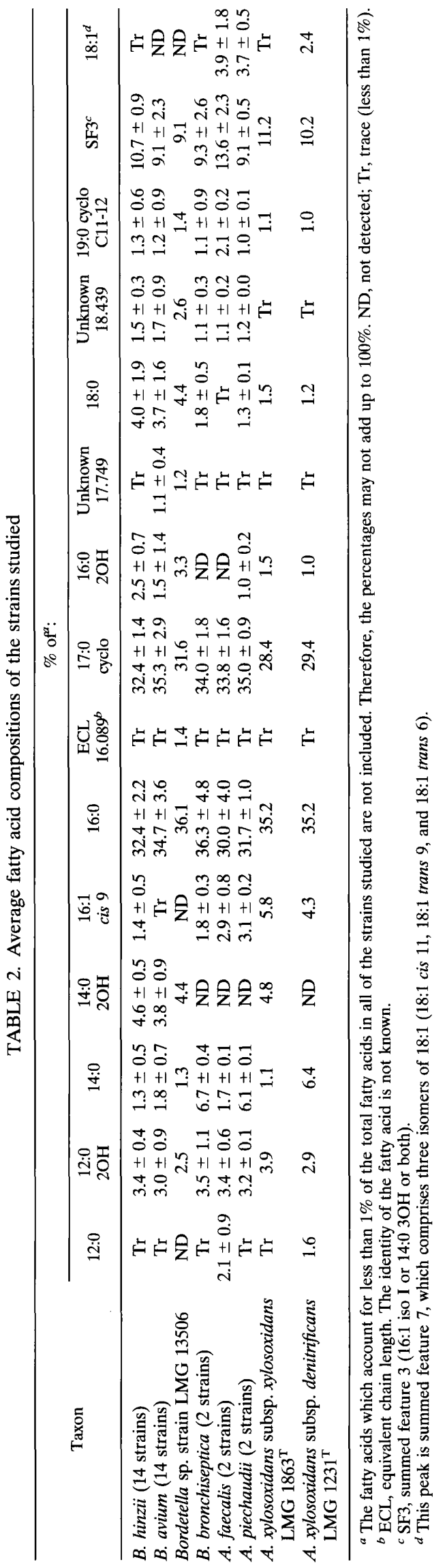




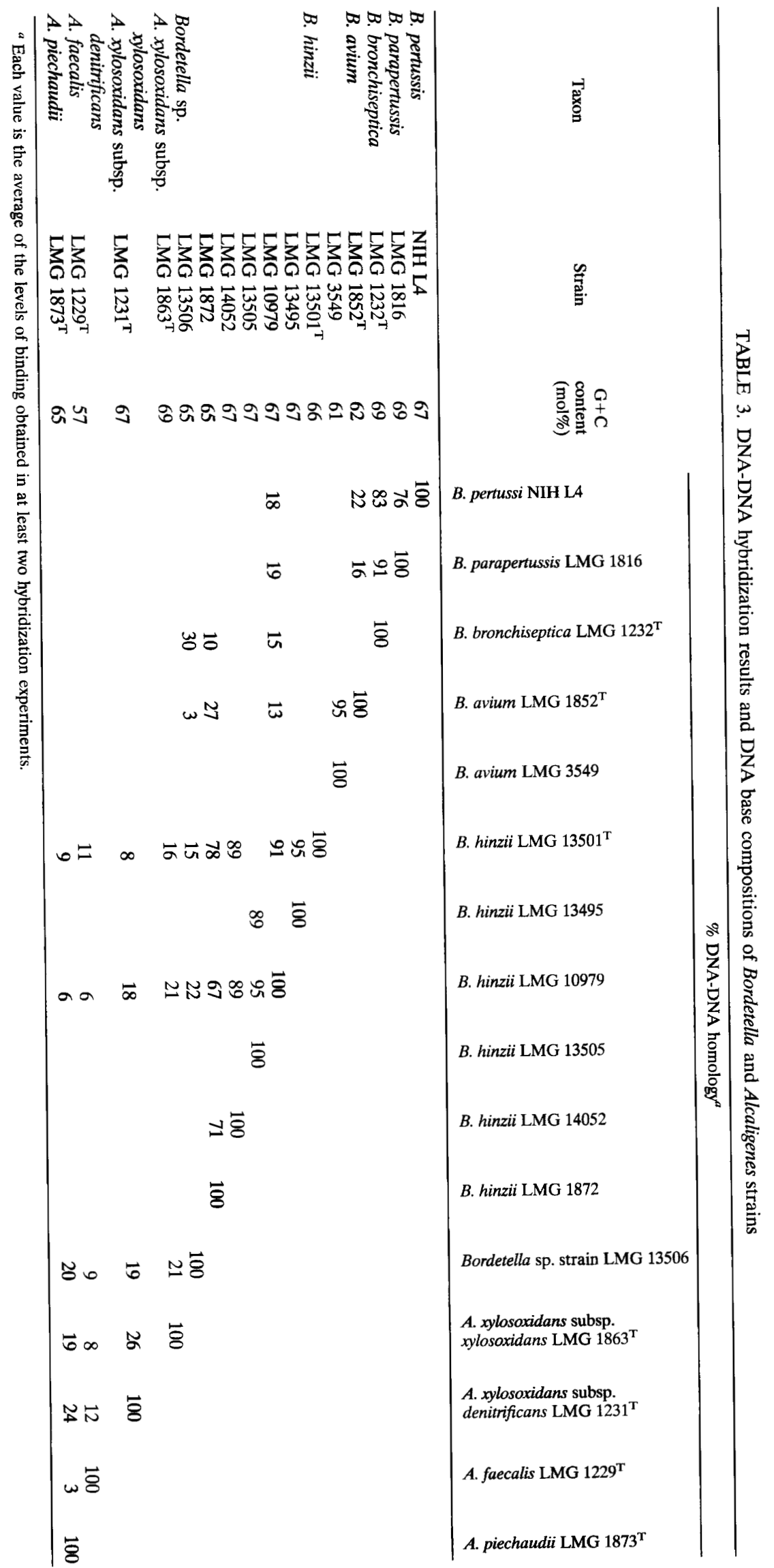


TABLE 4. $T_{m(e)}$ values of the DNA-rRNA hybrids obtained with 23S rRNA of $B$. hinzii LMG $13501^{\mathrm{T}}$

\begin{tabular}{|c|c|}
\hline Source of DNA & $\begin{array}{c}T_{m(e)} \\
\left({ }^{\circ} \mathrm{C}\right)\end{array}$ \\
\hline 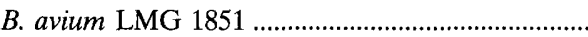 & .81 .0 \\
\hline B. avium LMG 3549 & .80 .3 \\
\hline B. bronchiseptica LMG $1232^{\mathrm{T}} \ldots$ & 81.2 \\
\hline 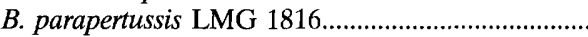 & .80 .7 \\
\hline 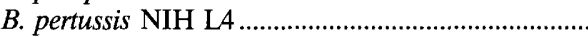 & .81 .1 \\
\hline 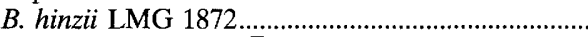 & 81.6 \\
\hline B. hinzii $\mathrm{LMG} 13501^{\mathrm{T}} \ldots \ldots \ldots \ldots \ldots$ & .81 .8 \\
\hline 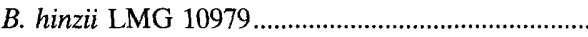 & .81 .8 \\
\hline 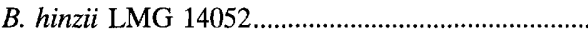 & .81 .8 \\
\hline 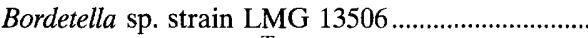 & .78 .3 \\
\hline 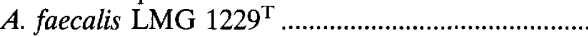 & .74 .3 \\
\hline A. xylosoxidans subsp. xylosoxidans $\mathrm{LMG} 1863^{\mathrm{T}} .$. & 80.3 \\
\hline A. xylosoxidans subsp. denitrificans $\mathrm{LMG} 1231^{\mathrm{T}}$.. & .79 .7 \\
\hline 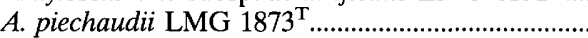 & .80 .6 \\
\hline
\end{tabular}

esculin, and assimilation of D-glucose, L-arabinose, D-mannose, D-mannitol, $N$-acetylglucosamine, maltose, and D-gluconate. Assimilation of citrate and phenyl acetate and oxidase activity were always positive.

All of the remaining characteristics were strain or taxon dependent (Table 5).

\section{DISCUSSION}

We performed a polyphasic taxonomic study to clarify the phylogenetic position of a taxon previously referred to as $A$. faecalis type II, TC (turkey coryza) bacterium type II, Alcaligenes sp. strain $\mathrm{C}_{2} \mathrm{~T}_{2}$ or $B$. avium-like $(1,3,19,20,31)$. In this study, strains of $B$. avium, $B$. pertussis, $B$. parapertussis, $B$. bronchiseptica, $A$. faecalis, $A$. piechaudii, $A$. xylosoxidans subsp. xylosoxidans, and $A$. xylosoxidans subsp. denitrificans were included as reference strains because members of the genera Bordetella and Alcaligenes are closely interrelated and hard to differentiate on the basis of genotypic and phenotypic criteria $(13,22,23)$. Three unclassified human clinical isolates were considered as well (Table 1).

The results of our study allowed us to assign 12 veterinary isolates and 2 human clinical strains to a new species, $B$. hinzii.

Species delineation by whole-cell protein electrophoresis. SDS-PAGE of whole-cell proteins and numerical comparisons of the protein patterns are often used to compare large numbers of bacteria and to group closely related strains (30, 37). A visual comparison of the protein profiles of all of the strains which we studied corroborated the initial phenotypic identification of six Belgian chicken isolates (LMG 10973 through LMG 10978) as B. avium (18). Although the B. avium strains were subdivided into two clusters on the basis of the results of a numerical analysis of their protein patterns, DNA-DNA hybridization data confirmed that these strains constituted a genotypically homogeneous species (Table 3 ), as determined previously in a DNA-rRNA hybridization study (22).

The 2 remaining Belgian field isolates (LMG 10979 and LMG 10980), the 10 Australian strains of the B. avium-like taxon, and 2 unclassified human clinical isolates produced very similar protein profiles (Fig. 1). As explained above, subdivision of these strains into two clusters on the basis of the results of a numerical analysis of their protein patterns was primarily due to a single dense protein band with a variable molecular weight of about 33,000 . Similar variable dense protein bands that influence the clustering sequences of strains within species

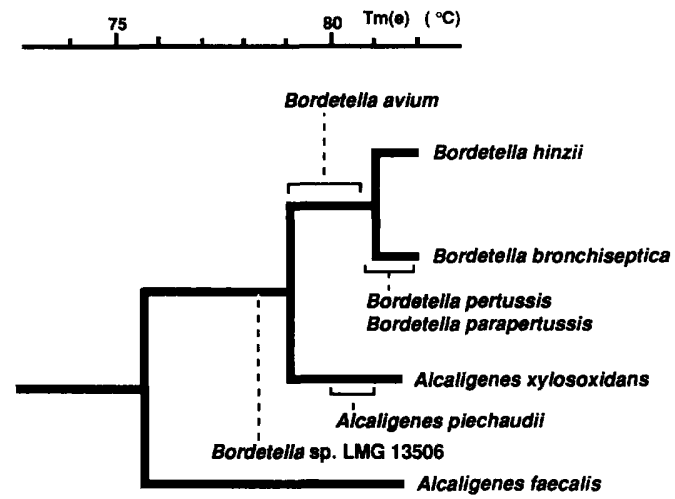

FIG. 2. Simplified rRNA cistron similarity dendrogram of the family Alcaligenaceae. The dashed lines show the positions of taxa for which no labeled rRNAs were prepared. The average linkage levels were calculated by using the $T_{m(e)}$ values shown in Table 4 and previously published values (13).

have been reported in several other genera and can be omitted from numerical analyses to enhance species differentiation (reviewed in reference 9). As deduced from the very similar protein contents and confirmed by DNA-DNA hybridization data, the strains belonging to the two clusters and strain LMG 1872 constitute a homogeneous species (DNA binding values, $>67 \%$ ).

Taxonomic position of $\boldsymbol{B}$. hinzii. Figure 2 shows the phylogenetic position of $B$. hinzii within the family Alcaligenaceae, as determined by DNA-rRNA hybridization. The $B$. hinzii strains constitute a separate rRNA branch, and $B$. pertussis, $B$. parapertussis, and $B$. bronchiseptica are its closest neighbors [differences in $T_{m(e)}$, up to $1^{\circ} \mathrm{C}$ ] (Table 4). B. avium and members of the $A$. xylosoxidans rRNA branch (A. xylosoxidans and $A$. piechaudii) are somewhat further removed [differences in $T_{m(e)}$, up to $2^{\circ} \mathrm{C}$ ] (Fig. 2), which confirms and extends findings obtained by comparative analysis of $23 \mathrm{~S}$ rRNA sequences (27). DNA-DNA hybridization studies did not reveal significant DNA binding with $B$. pertussis, $B$. parapertussis, and $B$. bronchiseptica or with other members of the Alcaligenaceae (Table 3).

Chemotaxonomic characteristics of $B$. hinzii. Several studies have focused on chemotaxonomic characteristics of $B$. avium and related bacteria $(15,20,26)$. In this study, the major fatty acid components of all of the strains examined were 16:0, 17:0 cyclo, and summed feature 3 (probably 14:0 3OH) (Table 2); these findings generally corroborate previously published data. Minor quantitative differences have been reported between $B$. avium and $B$. hinzii strains when the organisms were cultivated under strictly defined conditions $(20,26)$. These differences could not be detected under the conditions which we used, and hence, we could not differentiate $B$. avium from $B$. hinzii (Table 2). Furthermore, we could not differentiate $A$. piechaudii from A. xylosoxidans subsp. denitrificans (Table 2). All other species or subspecies could be differentiated on the basis of qualitative or quantitative differences (or both) in minor components. Strains could not be differentiated on the generic level, which further substantiates the genotypic interrelatedness of the genera Bordetella and Alcaligenes (13).

In addition, $B$. hinzii, B. avium, B. pertussis, B. bronchiseptica, $A$. faecalis, and $A$. xylosoxidans subsp. denitrificans have all been reported to contain ubiquinone 8 as their major respiratory quinone along with trace amounts of ubiquinone $9(7,15$, $35)$.

Phenotypic characterization of $\boldsymbol{B}$. hinzii. Phenotypic studies of $B$. hinzii strains have always focused on organisms derived 
TABLE 5. Phenotypic characteristics of the strains examined

\begin{tabular}{|c|c|c|c|c|c|c|}
\hline \multirow[b]{2}{*}{ Characteristic } & \multicolumn{3}{|c|}{ B. hinzii } & \multirow{2}{*}{$\begin{array}{c}\text { B. avium } \\
\text { ATCC } 35086^{\mathrm{T}}\end{array}$} & \multirow{2}{*}{$\begin{array}{l}\text { B. bronchiseptica } \\
\text { ATCC } 19395^{\mathrm{T}}\end{array}$} & \multirow{2}{*}{$\begin{array}{l}\text { A. faecalis } \\
\text { ATCC } 8750^{\mathrm{T}}\end{array}$} \\
\hline & $\begin{array}{l}\text { General reaction } \\
\text { result }\end{array}$ & $\begin{array}{l}\text { Reaction of } \\
\text { LMG } 13501^{\mathrm{T}}\end{array}$ & Aberrant strains & & & \\
\hline $\begin{array}{l}\text { Urease activity (in Christensen's } \\
\text { medium) }\end{array}$ & $\mathrm{V}(2 / 14)^{a}$ & - & LMG 13497, LMG 13499 & - & + & - \\
\hline $\begin{array}{l}\text { Urease activity (in API 20NE } \\
\text { system) }\end{array}$ & - & - & & - & + & - \\
\hline Nitrate reduction & - & - & & - & + & - \\
\hline \multicolumn{7}{|l|}{ Alkali production from: } \\
\hline Acetamide & + & + & & + & - & - \\
\hline Adipate & + & + & & + & + & - \\
\hline Glycine & $\mathrm{V}(9 / 14)$ & + & $\begin{array}{l}\text { LMG 13494, LMG 13497, LMG } \\
\text { 13498, LMG 13499, LMG } \\
\text { 13505 }\end{array}$ & - & + & + \\
\hline Malonamide & + & + & & - & + & + \\
\hline Malonate & + & + & & - & + & + \\
\hline Propionamide & + & + & & + & + & + \\
\hline Valerate & + & + & & - & + & + \\
\hline Assimilation of caprate & $\mathrm{V}(12 / 14)$ & + & LMG 1872, LMG 10980 & - & - & + \\
\hline Assimilation of adipate & + & + & & + & + & - \\
\hline Assimilation of L-malate & + & + & & + & - & + \\
\hline API 20NE profile & $0000077(12 / 14)$ & 0000077 & LMG 1872, LMG $10980^{b}$ & 0000067 & 1200027 & 0000057 \\
\hline
\end{tabular}

${ }^{a}$ The numbers in parentheses are the numbers of strains that are positive for the characteristic. + , present in all strains; - , absent in all strains; $V$, strain-dependent reaction result.

${ }^{b}$ The API $20 \mathrm{NE}$ profile of these strains is 0000067 .

from veterinary sources, with the main objective being the differentiation of $B$. hinzii from $B$. avium $(1,3,19,31)$. $B$. hinzii strains have been reported to be different from $B$. avium strains in the following characteristics: $B$. hinzii strains are not able to agglutinate erythrocytes from chickens, turkeys, humans, and guinea pigs and are able to grow in the presence of $6.5 \% \mathrm{NaCl}$, in a minimal essential medium, in Simmons citrate agar, and in the presence of cetrimide $(1,19,31)$. In addition, $B$. hinzii strains alkalinize considerably more substrates than $B$. avium strains and decarboxylate histidine $(1,19,31)$. However, often the inoculum size and method used may influence the results of tests, as has been demonstrated for several of these characteristics $(1,5,16)$.

We evaluated a number of classical phenotypic tests and the API 20NE MicroTest system for their ability to differentiate $B$. avium, B. hinzii, B. bronchiseptica, and $A$. faecalis. Alkali production from malonamide, malonate, and valerate clearly differentiated $B$. hinzii from $B$. avium (Table 5). B. hinzii strains also differed from $B$. avium in the API 20NE tests by their ability to assimilate caprate (Table 5). However, two aberrant strains were incorrectly identified as $B$. avium (Table 5). Other characteristics that can be used to differentiate $B$. hinzii, $B$. avium, $B$. bronchiseptica, and $A$. faecalis are shown in Table 5.

The absence of motility, the absence of citrate utilization, and fastidious growth characteristics readily differentiate $B$. pertussis from $B$. hinzii (39). In addition, it is unlikely that the various pertussis virulence factors (39) are present in B. hinzii. The absence of motility, the absence of oxidase acitivity, the presence of urease acitivity, and browning of the growth medium differentiate $B$. parapertussis from $B$. hinzii (39).

Clinical significance of field isolates. The pathological signs associated with the six field isolates identified as B. avium (LMG 10973 through LMG 10978) included coryza-like symptoms, tracheitis, and polyserositis and support the hypothesis that $B$. avium is pathogenic in chickens.

Twelve $B$. hinzii strains were obtained from the usual sources (i.e., the respiratory tracts of turkeys or chickens) (Table 1). The available clinical histories of these organisms did not suggest that they are pathogenic. The inclusion of human clinical isolates in this taxon has not been reported previously. Strain LMG 1872 was isolated from sputum and was originally identified as $A$. faecalis (24). Several taxonomic studies demonstrated that this isolate belongs to the Bordetella-Alcaligenes group but failed to classify it properly $(13,22,24)$. No data on the clinical significance of this strain are extant. A second human isolate, LMG 14052, was isolated from a human immunodeficiency virus-infected male (8). This strain grew in all four of four blood cultures drawn from the patient, and this episode of bacteremia required hospitalization. Intravenous antibiotic therapy was successful, but the patient did not have any evidence of respiratory illness or a history of exposure to birds. This case suggests that $B$. hinzii may be a previously unidentified human pathogen that does not necessarily cause disease via the respiratory tract or exist only in birds.

Description of Bordetella hinzii sp. nov. Bordetella hinzii (hin'zi.i. N. L. gen. n. hinzii [of Hinz], named in honor of K.-H. Hinz, a German microbiologist who has contributed much to our knowledge of avian isolates belonging to the genus Bordetella). $B$. hinzii cells are gram-negative, nonsporulating rods that are motile by means of peritrichous flagella. Two distinct colony types occur. Some strains produce round, raised, glistening, greyish colonies about $2 \mathrm{~mm}$ in diameter following $48 \mathrm{~h}$ of incubation at $37^{\circ} \mathrm{C}$ in air containing $5 \% \mathrm{CO}_{2}$. Under the same conditions other strains produce flat, dry, crinkled colonies that are up to $5 \mathrm{~mm}$ in diameter. Nitrates are not reduced, and oxidase and catalase activities are present. Urease activity in Christensen's medium is strain dependent. Alkali is produced from the following substrates: acetamide, adipate, malonamide, malonate, valerate, and propionamide. Production of alkali from glycine is strain dependent. As determined by the API 20NE MicroTest system, the following characteristics are always negative: reduction of nitrate, production of indole, production of acid from glucose, urease, arginine dihydrolase, and $\beta$-galactosidase activities, liquefaction of gelatin, hydrolysis of esculin, and assimilation of D-glucose, L-arabinose, D-mannose, D-mannitol, $N$-acetyl-glucosamine, maltose, and 
D-gluconate. Assimilation of adipate, malate, citrate, and phenyl acetate and oxidase activity are always positive. Assimilation of caprate is strain dependent. The API $20 \mathrm{NE}$ profile of most strains is 0000077 ; the profile of other strains is 0000067 , which is identical to the profile of $B$. avium strains.

The major fatty acid components of all of the strains examined are 16:0,17:0 cyclo, and summed feature 3 (probably 14:0 3OH). Ubiquinone 8 and trace amounts of ubiquinone 9 are the respiratory quinones.

Most strains have been isolated from respiratory tracts of turkeys and chickens. Experimental infections in turkey poults have shown that $B$. hinzii is nonpathogenic (19). Recent studies at the Animal Research Institute in Yeerongpilly, Australia, have shown that the Australian isolates of $B$. hinzii are nonpathogenic for 1-day-old chickens and turkey poults (2). The available clinical histories do not provide strong evidence that this organism plays a role in respiratory disease (3, 18). Two strains have been isolated from humans; one was responsible for bacteremia, and the other was isolated from sputum.

The DNA base composition is between 65 and $67 \mathrm{~mol} \%$ $\mathrm{G}+\mathrm{C}$. The type strain is LMG 13501 (= TC58), which was isolated from a chicken trachea in Australia; its $\mathrm{G}+\mathrm{C}$ content is $66 \mathrm{~mol} \%$.

All B. hinzii strains have been deposited in the Laboratorium Microbiologie Gent Culture Collection.

Taxonomic position of strain LMG 13506. Strain LMG 13506 was isolated in a mixed culture from an ear swab of a patient suffering from chronic otitis media (14). This strain exhibited the typical biochemical reactions of $B$. avium but had a different pattern of antimicrobial resistance. DNA-rRNA hybridization data confirmed that this strain belongs to the family Alcaligenaceae (Table 4). However, the absence of significant DNA binding values when this organism was tested with reference strains belonging to all Bordetella and Alcaligenes species that have been described indicates that it represents yet another novel species within this rRNA cluster. We provisionally designated this strain Bordetella sp. as it resembles or is virtually indistinguishable from $B$. avium in its biochemical, protein, and fatty acid profiles (Fig. 1 and Table 2) (14).

\section{ACKNOWLEDGMENTS}

We thank Urbain Torck and Dirk Dewettinck for excellent technical assistance.

We thank all depositors of strains listed in Table 1. P.V. is indebted to the National Fund for Scientific Research (Belgium) for a position as a postdoctoral research fellow. K.K. is indebted to the Fund for Medical Scientific Research, Belgium, for research and personnel grants. Part of the research was performed in the framework of CEC BRIDGE project BIOT-CT91-0294.

\section{REFERENCES}

1. Berkhoff, H. A., and G. D. Riddle. 1984. Differentiation of Alcaligenes-like bacteria of avian origin and comparison with Alcaligenes spp. reference strains. J. Clin. Microbiol. 19:477-481.

2. Blackall, P. J. Unpublished data.

3. Blackall, P. J., and C. M. Doheny. 1987. Isolation and characterisation of Bordetella avium and related species and an evaluation of their role in respiratory disease in poultry. Aust. Vet. J. 64:235-239.

4. Blackall, P. J., and J. G. Farrah. 1985. Isolation of Bordetella avium from poultry. Aust. Vet. J. 62:370-372.

5. Blackall, P. J., and J. G. Farrah. 1986. An evaluation of two methods of substrate alkalinisation for the identification of Bordetella avium and related organisms. Vet. Microbiol. 11:301-306.

6. Boycott, B. B., H. R. Wyman, and F. C. Wong. 1984. Alcaligenes faecalis rhinotracheitis in Manitoba turkeys. Avian Dis. 28:1110-1114.

7. Busse, J., and G. Auling. 1988. Polyamine pattern as a chemotaxonomic marker within the Proteobacteria. Syst. Appl. Microbiol. 11:1-8.
8. Cookson, B. T., P. Vandamme, L. Carlson, A. Larson, J. V. H. Sheffield, K. Kersters, and D. H. Spach. 1994. Bacteremia caused by a novel Bordetella species, " $B$. hinzii." J. Clin. Microbiol. 32:2569-2571.

9. Costas, M. 1992. Classification, identification, and typing of bacteria by the analysis of their one-dimensional polyacrylamide gel electrophoretic protein patterns, p. 351-408. In A. Chambrach, M. J. Dunn, and B. J. Radola (ed.), Advances in electrophoresis, vol. 5. VCH Verlagsgesellschaft, Weinheim, Germany.

10. Cowan, S. T. 1974. Cowan and Steel's manual for the identification of medical bacteria, 2nd ed. Cambridge University Press, Cambridge.

11. De Ley, J. 1970. Reexamination of the association between melting point, buoyant density, and chemical base composition of deoxyribonucleic acid. J. Bacteriol. 101:738-754.

12. De Ley, J., H. Cattoir, and A. Reynaerts. 1970. The quantitative measurement of DNA hybridization from renaturation rates. Eur. J. Biochem. 12:133-142.

13. De Ley, J. P. Segers, K. Kersters, W. Mannheim, and A. Lievens. 1986. Intra- and intergeneric similarities of the Bordetella ribosomal ribonucleic acid cistrons: proposal for a new family, Alcaligenaceae. Int. J. Syst. Bacteriol. 36:405-414.

14. Dorittke, C., P. Vandamme, K.-H. Hinz, E.-M. Schemken-Birk, and C. H. Wirsing von König. Isolation of an unusual Bordetella-like organism from a human source. Submitted for publication.

15. Fletcher, M. T., P. J. Blackall, and C. M. Doheny. 1987. A note on the isoprenoid quinone content of Bordetella avium and related species. J. Appl. Bacteriol. 62:275-277.

16. Hinz, K.-H., and G. Glünder. 1986. Identification of Bordetella avium sp. nov. by the API 20NE system. Avian Pathol. 15:611-614.

17. Hinz, K.-H., G. Glünder, and H. Luders. 1978. Acute respiratory disease in turkey poults caused by Bordetella bronchiseptica-like bacteria. Vet. Rec. 103:262-263.

18. Hommez, J. Unpublished data.

19. Jackwood, M. W., Y. M. Saif, P. D. Moorhead, and R. N. Dearth. 1985. Further characterization of the agent causing coryza in turkeys. Avian Dis. 29:690-705.

20. Jackwood, M. W., M. Sasser, and Y. M. Saif. 1986. Contribution to the taxonomy of the turkey coryza agent: cellular fatty acid analysis of the bacterium. Avian Dis. 30:172-178.

21. Kersters, K., and J. De Ley. 1984. Genus Alcaligenes Castellani and Chalmers 1919 , 936 ${ }^{\text {AL }}$, p. 361-373. In N. R. Krieg and J. G. Holt (ed.), Bergey's manual of systematic bacteriology, vol. 1. The Williams \& Wilkins Co., Baltimore.

22. Kersters, K., K.-H. Hinz, A. Hertle, P. Segers, A. Lievens, O. Siegmann, and J. De Ley. 1984. Bordetella avium sp. nov., isolated from the respiratory tracts of turkeys and other birds. Int. J. Syst. Bacteriol. 34:56-70.

23. Kiredjian, M., B. Holmes, K. Kersters, I. Guilvout, and J. De Ley. 1986. Alcaligenes piechaudii, a new species from human clinical specimens and the environment. Int. J. Syst. Bacteriol. 36:282-287.

24. Kiredjian, M., M. Popoff, C. Coynauly, M. Lefêvre, and M. Lemelin. 1981. Taxonomie du genre Alcaligenes. Ann. Inst. Pasteur Microbiol. 132B:337374.

25. Kloos, W. E., N. Mohapatra, W. Dobrogosz, J. W. Ezzell, and C. R. Manclark. 1981. Deoxyribonucleotide sequence relationships among Bordetella species. Int. J. Syst. Bacteriol. 31:173-176.

26. Moore, C. J., H. Mawhinney, and P. J. Blackall. 1987. Differentiation of Bordetella avium and related species by cellular fatty acid analysis. J. Clin. Microbiol. 25:1059-1062.

27. Müller, M., and A. Hildebrandt. 1993. Nucleotide sequences of the $23 \mathrm{~S}$ rRNA genes from Bordetella pertussis, B. parapertussis, B. bronchiseptica and $B$. avium, and their implications for phylogenetic analyses. Nucleic Acids Res. 21:3320.

28. Panigraphy, B., L. C. Grumbles, R. J. Terry, D. L. Millar, and C. F. Hall. 1981. Bacterial coryza in turkeys in Texas. Poult. Sci. 60:107-113.

29. Pickett, M. J. 1980. Nonfermentative gram negative bacilli. Scientific Developments Press, Los Angeles.

30. Pot, B., P. Vandamme, and K. Kersters. 1993. Analysis of electrophoretic whole-organism protein fingerprinting, p. 493-521. In M. Goodfellow and A. G. O'Donnell (ed.), Modern microbial methods. Chemical methods in bacterial systematics. J. Wiley and Sons, Chichester, United Kingdom.

31. Rimler, R. B., and D. G. Simmons. 1983. Differentiation among bacteria isolated from turkeys with coryza (rhinotracheitis). Avian Dis. 27:491500.

32. Saif, Y. M., P. D. Moorhead, R. N. Dearth, and D. J. Jackwood. 1980. Observations on Alcaligenes faecalis infection in turkeys. Avian Dis. 24:665684.

33. Simmons, D. G., D. E. Davis, L. P. Rose, J. G. Gray, and G. H. Luginbuhl. 1981. Alcaligenes faecalis-associated respiratory disease of chickens. Avian Dis. 25:610-613.

34. Stainer, D. W., and M. J. Scholte. 1971. A simple chemically defined medium for the production of phase I Bordetella pertussis. J. Gen. Microbiol. 63:211-220.

35. Thiele, O. W., and G. Schwinn. 1973. The free lipids of Brucella melitensis 
and Bordetella pertussis. Eur. J. Biochem. 34:333-334.

36. Vandamme, P., P. Segers, M. Vancanneyt, K. Van Hove, R. Mutters, J. Hommez, F. Dewhirst, B. Paster, K. Kersters, E. Falsen, L. Devrieze, K.-H.

Hinz, and W. Mannheim. 1994. Description of Ornithobacterium rhinotracheale gen. nov., sp. nov. isolated from the avian respiratory tract. Int. J. Syst. Bacteriol. 44:24-37.

37. Vandamme, P., M. Vancanneyt, B. Pot, L. Mels, B. Hoste, D. Dewettinck, L. Vlaes, C. Van Den Borre, R. Higgins, J. Hommez, K. Kersters, J.-P. Butzler, and H. Goossens. 1992. Polyphasic taxonomic study of the emended genus
Arcobacter with Arcobacter butzleri comb. nov, and Arcobacter skirrowii sp. nov., an aerotolerant bacterium isolated from veterinary specimens. Int. J. Syst. Bacteriol, 42:344-356.

38. Van Landschoot, A., and J. De Ley. 1983. Intra- and intergeneric similarities of the rRNA cistrons of Alteromonas, Marinomonas (gen. nov.) and some other Gram-negative bacteria. J. Gen. Microbiol. 129:3057-3074.

39. Weiss, A. A. 1992. The genus Bordetella, p. 2530-2543. In A. Balows, H. G. Trüper, M. Dworkin, W. Harder, and K.-H. Schleifer (ed.), The prokaryotes, 2nd ed., vol. 2. Springer-Verlag, Berlin. 